\title{
Abbreviations
}

\author{
AMC American Movie Channel \\ CDA critical discourse analysis \\ CIA Central Intelligence Agency \\ FBI Federal Bureau of Investigation \\ HBO Home Box Office \\ IR International Relations \\ ISIL Islamic State of Iraq and Levant \\ ISIS Islamic State of Iraq and Syria \\ OWI Office of War Information \\ VHS Video Home System
}




\section{SPOILER ALERT}

This book contains detailed discussion of a number of today's great television shows. There are, necessarily, major spoilers throughout. 